\title{
A NOTE ON THE TRANSLATION
}

\author{
CORINE TACHTIRIS
}

The fact of women loving women is more easily emphasized grammatically in French since nouns, adjectives, and other parts of speech are gendered. I have tried to bring this into the translation by experimenting at times with grammatical gender in English. I owe the neologism lovhers to Barbara Godard's translation of Nicole Brossard's Amantes.

Duala words in the French are generally italicized only the first time they appear in the translation. Some are not italicized at all in recognition of the multilingual nature of the stories' settings, of the text itself, and the world in which we live. English words italicized in the French generally remain in italics in the translation.

The goals and strategies of the translation are described in greater detail in my article, "Giving Voice: Translating Speech and Silence in Frieda Ekotto's Don't Whisper Too Much," Translation Review 98, no. I (2017): 49-64. 
